\title{
A HEROIC TALE'S TRAVEL FROM SIBERIA TO THE BALTO-FINNIC PEOPLES
}

\section{Kristi Salve}

\begin{abstract}
The article concerns a fairy tale from A. Andreiev's fairy-tale index, namely AA 967, which has greatly interested Russian researchers because of its connection with bylina. However, this story is not of East Slavic origin but has enetered the Russians' repertoire as a substrate. The case is even more interesting since the same story is also known in far East Siberia, among the Paleoasiatic Kets and Samoyed Selkups. The Ket stories are vividly Siberian narratives of inter-tribal feud. The same applies to the story's western distribution's periphery - it has been told as a true story in Finland and P.-L. Rausmaa has indexed it as a historical legend.

Finnish and Ket versions are similar, while Karelian, Vepsian and probably also the version spread to Russians from them has obtained fairy tale motifs. Undisputable is the common origin of all these stories: coinciding facts are too complex to assume random similarity. The article also discusses whether the narrative is hostile towards women.
\end{abstract}

Keywords: fairy tale, oral history, bylina, Baltic Finns, Samis, Siberian indigenous peoples, substrate, family relations, betraying wife.

This ancient story caught my attention on a summer day in 1981 in the Central Vepsian village of Ladva. The day was boiling hot and treading along a village street caused real torment for me and my companion. So we more or less knocked on the door of the first house on our way. At first it seemed that our visit to this house would be a brief one, as our hosts were a middle-aged couple, who usually do not make very productive informants. But our prejudices proved wrong. Inside the pleasantly cool house we were asked to sit down and our hostess offered us fresh milk, bread and cloudberry jam. So we stayed there and talked about ourselves and our reasons for coming, about our search for old songs and tales. On that our host mentioned that in the old days they really used to tell all kinds of stories, often quite scary ones, in the evenings. He also reminisced about the storytellers and narrative situations of his childhood, so we decided to turn on the tape recorder, which proved a very clever move. As soon as the recorder was turned on he told us a reportedly true story he had heard from his father. Even the scene was well known - the events had taken place east of their village, across Lake Vahterjärv. 
The more I listened, the more agog I became. And finally, when the storyteller finished, the question which had pounded in my head was answered - yes, it definitely was the same story I had read as a text recorded from the Kets (Yenisei Ostyaks) in Eastern Siberia. The distance between these two areas is truly astonishing, indicating also that the story must be terribly old.

After returning to Estonia I told the story to some of my closest friends, who inquired about the more interesting findings of the expedition, and having heard my story two of them asked me whether it could be really true. I replied that it could hardly happen there and in the particular way like my informant had told me, conceding that something analogous may have happened somewhere else and indicating to the Ket variants, and confidently explicated that this must have been a migratory plot, in which case the issue of trueness is irrelevant.

But the story itself had started to intrigue me. I decided to look further into it and managed to find new texts, studies and catalogue data. Here I would like to express my gratitude to Marje Joalaid who pointed to another Vepsian variant held in the collection of the University of Tartu, to the late Professor Uku Masing, through whom I learned that the story was also known among the Selkups, and to Kari Laukkanen, who was kind enough to procure me copies of the texts preserved in the Folklore Archives of the Finnish Literature Society.

So much about the background of the story. Those who have read thus far are probably already curious about the tale. In the following I will present variants from three different traditions in a slightly abbreviated and concentrated form. The first of the variants was known in Finland:

Once there lived a Finn in the Viensuu village on the Viensuu River, Pielisjärve parish. This Finn had forbidden his wife to throw coal into the river to keep their location secret from enemies. The wife was disobedient, threw coal in the river and, soon, the enemies came. The Finn was tied up and left inside the house with his two children - the older daughter and the younger brother. The enemy chief took the Finn's wife and went to sleep in the barn, the rest of the eleven men went to sleep in the sauna. When all was quiet, the father woke up his daugh- 
ter and asked her to hand him a knife lying on the shelf. The daughter answered: "Be quiet, or I will tell the new father!" The father calmed her down and told her to get back to sleep. When she was sound asleep, the father woke his son and asked him the same thing. The son was so young that he didn't reach the knife on the shelf and let it drop. The Finn cut through the bonds and found himself an axe. The next morning the chief came to the house with his wife and told that he had dreamed about having caught a grouse hatchling. The Finn answered that he had dreamed of catching two. Then he took the axe and killed the enemy, then his wife and his daughter. After that he went to the sauna, closed the door with a strong cudgel and lit it on fire, keeping watch under the window holding the axe. The Russians burnt in.

The next text example is a Vepsian variant which was recorded some dozen years prior to the story that I was told.

Once there lived a very strong man Biboi in the Kapshjärv area. He was living outside the village alone with his wife, son and daughter. Twelve robbers came there and their chief got acquainted with Biboi's wife. But they were not strong enough to defeat Biboi. The woman betrayed his secret: after bathing in the sauna and drinking strong kvass, Biboi becomes weak. So the robber chief and wife heated the sauna and Biboi went to the sauna. Returning from the sauna Biboi drank the kvass his wife offered him and weakened. The robbers tied him up and left him in the house, but the chief and Biboi's wife went to the other wing of the house. The rest of the robbers slept in the sauna. A lamp was lit in Biboi's house. In came the daughter, whom the father asked to burn through the bonds. She arrogantly refused, and promised to tell her mother and "uncle". Then the son came. The father repeated his wish and the son readily complied. Freed from bondage, Biboi went to the sauna and pulled down its roof upon the robbers so that they perished under the ruins. Then he returned to the house. The next morning the chief came to him to ask about his dream. Biboi answered that he had bagged 11 grouses in his dream. The robber grew angry: he thought Biboi's joke as particularly offensive. Biboi jumped up, grabbed the robber by the leg and crushed him dead against the wall. He tore his wife open 
in the middle and killed his daughter. After having his revenge Biboi and his son moved elsewhere. - Ozera [Lakes].

The last example takes us to the eastern border of the story's area of distribution. This is one of three texts recorded from the Kets in the Yenisei watershed.

A Ket has a wife, a daughter and a son. Four Yuraks come to them, look at the mother and the daughter, find them beautiful and decide to take them. The father is tied to a tree and left outside to be eaten by gnats. A Yurak asks the mother: "Do you need your husband?" - "I probably would, but you have already tied him up, so what use he is to me now." The sister is also asked: "Do you need your father?" She answers: "Gnats may take him, I have a fat father now." The Yurak dares her to go outside and spit his father in the face. Ilget, the son, is forced to do the same, under threat of death. Ilget goes to his father and cries. The father tells him to wait until everyone is asleep, then he should take a spear and sneak out. Ilget follows his advice. He cuts through the father's bonds. The father takes the spear, enters the house and kills all the Yuraks. Then he reminds his wife and daughter what they said to him earlier. Both assure him that they would not need a fat man/ father, the Yurak. The daughter even says: "I need my own flesh and blood." The man puts them both to excruciating death and settles elsewhere with his son.

Next to the Finnish, Vepsian and Ket the story was also known in the Sami, Karelian, Selkup and Russian tradition. But I hope the three examples would suffice to characterise the rest of the extant Finnish, Vepsian, Ket, etc. variants. On a general note I might say that the Karelian and Russian, and quite unexpectedly also Selkup variants bear more resemblance to the Vepsian variants, whereas the Sami ones are closer to the Finnish and Ket variants.

Following this foreshadowing I will attempt to provide an overview of the main motifs absent or strongly differing from those in the sample texts, thus characterising the interrelation of different traditions. This will be accompanied by an overview of the various treatments of the story, either in the form of catalogues 
or studies published so far. Through evaluating the results of the work so far I will also present my own viewpoint. The basic issues that will be presented here are traditional - the origin of the story and the main plot. Nevertheless, I have decided not to follow the example of the Finnish school and will not attempt to reconstruct the main plot too enthusiastically, only to treat the result as something that was in fact told millennia ago. Since this would be a hopeless attempt, as would be the attempt to locate the story's most likely place of origin, I will provide only the more general arguments.

Already the fact that the story under discussion has been included in various catalogue registers indicates that it has been unique and significant. But is it a folk tale or a legend? The answer to this question differs from culture to culture on various reasons. In the Finnish tradition the story is quite explicitly legendary, and Pirkko-Liisa Rausmaa, Finnish scholar and an expert in folk tale repertoire, has categorised it among tales about war and hostility under the subcategory "Resistance to the enemy" in her register of historical and regional legends (Rausmaa 1969: 25). Rausmaa has listed 13 variants to the story, but closer inspection of the copies revealed that the number of the type's Finnish variants is considerably smaller. Some variants registered as Finnish are in fact Karelian variants; other texts have been included because the compiler of the register has regarded the motif of casting leavings (coal, shavings, etc.) into the river, which is included also in the above Finnish variant, as a structural part of the story. The motif, however, may appear independently but also as a compound motif of other tales. A tale which opens with this motif may end quite differently - with the death of the disobedient wife or in a different conflict between the man and the enemies. Bearing this in mind there are only five authentic Finnish variants of the tale, four of which mention nothing about the man prohibiting his wife to throw coal, etc. into the river. The above Finnish variant is also exceptional among the five variants in that it is the only one with a nameless protagonist.

The protagonist's anonymity and the motif of throwing refuse into the river in the opening of the tale is quite characteristic of Karelian variants, and is also typical to certain Russian variants 
in the distant periphery of the eastern coastal region around Lake Onega. Interestingly, this combination is also characteristic of the Sami and especially Selkup variants. In all the three Ket variants the hero attacked by the enemy is also nameless, but the variants lack the motif of casting leavings into the river.

N. Krinichnaya, a scholar from Petrozavodsk, has pointed out in her article on the folklore of natives and village settlers that prohibiting the throwing of refuse into the river and violating this prohibition is an ancient motif but its combination with other plots, like the one we have here, is more recent and accidental. Krinichnaya illustrates her argument with an example of Yakut folklore, where casting various objects into the river has a positive connotation - the hero is purposely advised to do that, so that his kins living downstream would be notified of his arrival (Krinichnaya 1978: 28-32).

The presented Finnish variant first mentions an unspecified enemy, who in the end are identified as Russians. Similarly, in other Finnish variants, two of which have been published by Lauri Simonsuuri in his collection of local lore Vaimo vainolaisten puolella - miehen kosto (Simonsuuri 1951 1984), the enemies have been identified as Russians, "vienalaiset", or Karelian Russians, or "ryssät", and are parallelly referred to as robbers. It is clear that in the Finnish tradition the story has been associated with the partisan wars waged in the border areas of the two countries during and after the Russian and Swedish wars. That the groups of pillagers consisted of Karelian Russians or "vienalaiset" has been mentioned only once; but ethnonyms "Russian" or "ryssät" in narrative history about periods of hostilities or other phenomena are often specifically applied to the Karelians. This is further confirmed by the fact that the "ryssät" usually have no problem with understanding the Finnish language and that their own lines are presented in the Karelian language.

Quite interestingly, the situation is never the other way around in Karelian variants the Finns never appear as enemies. Also, if no other nationalities are mentioned the enemies are merely robbers or plunderers. Robbers of undetermined ethnicity appear in the Karelian, but also in the Vepsian, Russian and Selkup variants. The group is usually limited to a mythic number, mostly 
either 12 or 40 . These numbers also appear in the otherwise legendlike Finnish variants, in some cases the number of robbers is even 50. Sometimes the great number of enemies is indirectly referred to in the episode of asking and telling about the dreams, like is the case in a Ket variant.

Similarly to the Finnish and unlike the Karelian, Vepsian, Russian and Selkup variants the enemies are of foreign ethnicity also in the Sami and Ket variants. The enemies in the Sami tale variants are the Balto-Finnic Chuds, whereas those in the Ket variants are Samoyed-Yuraks. Evidently, in the periphery of the tale's distribution area it is characteristic and should also be considered an authentic feature that the protagonist fights with members of a hostile tribe. This is confirmed by the survival of the story in the periphery, which is generally common to archaic elements, but also by the fact that the emergence of pillaging enemies in the story has introduced other folk tale motifs or at least references to them in the story.

The Finnish version thus bears similitude to the Sami and Ket variants in that the enemies are foreign members of the ethnic group with who the war was ceaselessly or intermittently waged. But there is also one remarkable difference - namely, in the Finnish variant the events are historically more determined. Although it is expressed rather indirectly, referring to the period as "vainoaika", or the period of hostilities, or (in a single text) as "suurena vainoaikana", the period of deep hostilities, and in some cases no reference is made to any historical period, it is evident that in the storytellers and audience's mind the events were associated with the early $18^{\text {th }}$ century period of "Isoviha", or Great Hate. (1713-1721). The most recent extraordinary events tend to become dominant in narrative history, and cause the merging of tales that were originally associated with earlier events. Talking about the "ryssät" as enemies was definitely common in Finland many centuries before, ever since the establishment of Russia's and Sweden's borders of authority.

The temporal setting of the Sami and Ket tales, however, cannot be even vaguely determined. Considering the strong mythologisation which is characteristic of the Chud lore we may assume that the events are dated to some prehistoric time. The Ket variants, however, do not provide even indirect reference to the tem- 
poral setting. The described conflict between hostile tribes may have taken place a century but also a millennium ago. Still, it is more likely that the story refers to the more distant rather than the recent past, otherwise the events may have been associated with named characters and places.

As I have already mentioned, in the variants of those traditions where the hero is attacked by robbers the story exhibits several fantastic features. The most important of these is the supernatural strength of the protagonist, which in turn triggers the affair between the robber chief and the wife, resulting in the loss of the hero's strength, after which the hero can be tied up. This explains why A. Andreev, while compiling the first East Slavonic folk tale register on the example of A. Aarne's tale type system, categorised the Russian variants known to him among the short story-like folk tales entitled "The Woodman and the Robbers" (AA 967). Unfortunately, this remarkable story has not been included separately in the international folk tale type register (AT), but is categorised under tale type AT 968, which contains widely heterogeneous tale repertoire of varying mentality, where the only common factor is that the robbers who appear among the tale's characters. In the new index of East-Slavonic tale types (SUS 1979) the tale is categorised as an individual type under the number $958^{* * * *}$. The type description imitates that of A. Andreev: “The robbers capture a woodman; the man's young son helps to free him from bonds; he kills the ataman, then pulled down the sauna roof on all the other robbers." Andreev notes a single variant, whereas the new index refers to the works by K. Chistov and Y. Smirnov, where dozens of variants have been registered and partly also published. The type description, evidently, does not mention the motif of throwing shavings in the water, the protagonist's heroic strength and the wife's treachery, which enabled to capture the man. But these aspects are secondary. Unfortunately, what is also missing is the type core - namely, the disloyalty of the wife and also the daughter. Regardless of this a reference in the Finnish Literature Society files to the Andreev register indicates that the description has enabled to determine the story's relation to the Finnish variants.

The originally fantastically large number of robbers must have had something to counterbalance the force. Consequently, the 
protagonist was attributed supernatural magic strength, and for the development of the plot the wife's foreshadowing treachery was introduced. The wife's crime is sometimes presented over several episodes: the robber chief tells the wife to find out the secret of her husband's strength, the wife reveals what she learned to the robber and the two cooperate in making him lose the magic strength. The motif is, of course, the well-known Delilah motif, which is of no consequence for the original plot. In the Ket variants the number of hostile Yuraks was four, two or one. Two and four can easily overpower one man, and there would be no need for the foreshadowing treachery of the wife. But in the variant where there is only one enemy, and one man is set fairly against another, it has been mentioned that the strong one (not in the supernatural way) was Yurak.

The loss of the magic strength in the variants it occurs is connected with bathing in the sauna, or overlooking or a violation of some command or prohibition related to it. In single variants the hero loses its strength after bedding the wife. This too is an old concept but I will not address it or explicate its origin and distribution here, because it has obviously joined the tale we are discussing later.

The varying motif of losing strength in connection with sauna is considerably more interesting in terms of the history of the tale. In several Finnish variants the male protagonist is captured in the sauna. Does this lead to the conclusion that the Finnish originally knew the fairytale-like variant about a hero of supernatural strength, which was rationalised later through attributing the hero the features of a local historical person? It is also possible that the sauna motif was borrowed from the Karelians and it was rationalised from the very beginning. Clearly, even a strong man, without his weapons and clothes, is vulnerable when attacked in the sauna.

The motif of magic strength and its subsequent loss as something too fantastic has been passingly mentioned also by several Karelian and Russian storytellers: all that the treacherous wife has to do is signal that her husband has gone to the sauna. But even here it remains questionable whether this means that the motif of losing strength did not became fixed everywhere where 
it spread in the Russian language, or the motif has been deliberately or unintentionally omitted by the more recent storytellers (as a large number of Russian variants have been recorded in the 1950s-1960s).

Representatives of foreign tribes and a hero of ordinary strength, or only slightly stronger, are very common elements. In several Sami and Finnish and in many Russian variants the strength of the man has been illustrated through examples. Interestingly, while in the fairytale-like plot the hero's supernatural strength and its loss are secondary motifs, then examples about the hero's strength are also secondary but originate from a different source. Although not related to the story discussed here, such examples, occurring either separately or merged with other plots, have been known in a very wide area among different peoples, among others also the Finno-Ugrians, including the Balto-Finnic people. Such demonstrations of physical strength are, for example, lifting or carrying a horse, or carrying rocks and logs. The most illustrative motif is lifting the house by its corner and placing skis or mittens under it in order to keep them being stolen or to tease the enemies. This motif was known among the Finns and also Estonians (Simonsuuri 1984: 261, 271, 273; ERA II 259, 263 (3) < Urv; RKM, Mgn II 2401 e < Krl). Clearly, the motif has not emerged independently but has spread from one culture to another, or has survived in the substratum after the Russianisation of the Balto-Finnic population in the present-day North-West Russia. In the Finnish and Estonian culture all the mentioned demonstrations of strength have often merged into series of motifs concentrated around heroes who are assigned specific names and to specific locations, and whom the Estonian scholar Oskar Loorits in his interesting article has called 'the hero prototypes' (Loorits 1927). Loorits argues that in the course of narration the originally great physical strength was gradually increased until reaching the actions that are physically impossible, and from this point on the man is replaced by a mythical figure, such as the Estonian epic hero Kalevipoeg.

In the Russian tradition, however, specific displays of strength and the accompanying motif according to which the hero, when hungry, is furious and even dangerous, are connected with another tale plot, which according to Y. Smirnov could be entitled "Rahta the Warrior". This plot may occur independently but also 
in combination with the tale plot AA *967. "Rahta the Warrior" is spread in a narrower area and occurs in a smaller number of variants, but has obviously been important enough to draw the Russian folklorists' attention to the plot discussed here. The plot of "Rahta the Warrior" is the source of the Russian bylina "Rahta Ragnozeski", and bylinas are traditionally considered one of the most distinguished genre of Russian folklore.

In his treatment of the relationship between bylina and narrative K. Chistov has also expressed his opinion about the tale type AA *967 (Chistov 1958; Chistov 1959). Since he had access only to Russian, Karelian and Sami variants, he could not avoid the mistake of considering the secondary motifs in the Russian and Karelian, partly also in the Sami variants as primary in the type. Chistov, however, noticed that the Sami variants were much more archaic. In the conclusion to the article he claims that the plot is an ancient piece of Sami or "Vessian" family heritage, which by the $9^{\text {th }}$ century must have passed on to the Karelian repertoire and by the $12^{\text {th }}-14^{\text {th }}$ century also to the Russian repertoire.

Concluding, thus, that the story was of Finno-Ugric origin, K. Chistov relied heavily on onomastics. Indeed, the toponyms of the area where the corresponding stories were spread among the Russianised population in the Russian language are predominantly Balto-Finnic. The tale's heroes' names (and those who appear in the bylina based on the plot), however, are conspicuously non-Slavonic. K. Chistov has pointed out that the most common name root, which appears in widely different phonetic forms (Rahta, Rahka, Rahkoi, Rak, Rahkul', Ragna, Rakh, Mikhaila Rakin) in the "Rahta the Warrior" as well as in the combined or independent plot of "The Woodman and Robbers", must be etymologically related to the name of the ancient Finnish deity who is mentioned in the foreword to M. Agricola's "Psalter" (Agricola has spelled it Rachkoi). Unfortunately, the scholar who courageously related the origin of the story to both the Sami and the "Vessians" overlooked the fact which would have greatly contributed to his speculation. Namely, the word 'rahkoi' appears as a suffix in the names of Vepsian mythological creatures, such as pä?irahkoi, or the house (home, hearth) spirit, and rihkenrahkoi, or the thresher spirit. So we have the Finnish or Vepsian names of spirits or deities and the hero's name from a Russian historical tale. This connection is interesting, but even more intriguing 
is the strong argument in support of the speculation that the Vepsians in particular might have played an important role in transmitting the tale to the Russian repertoire - namely, that the family name Rahkoshkin, derived from an ancient ancestor, is still common among the Vepsians. Upon my asking about the origin of her name, Tatyana Rahkoshkina, who lives in the village of Ozera (Järved), answered without much thinking about it: "People say that once there lived an old man called Rahkoi. The family name comes from his name." However, she could not say much more about this ancestor.

If it is certain that Rahkoi was a common personal name among the Vepsians, it seems surprising that in the Vepsian variant (the second text example above), which was recorded in the same village (or the variant recorded in the nearby Ladva village) the hero is not referred to by this name. The name Biboi, which appears in the example text, is also quite remarkable in many ways. First, the ethnic Vepsian names, like Biboi, are quite rare among the predominantly Orthodox names (though many appear in Vepsian forms). Like Rahkoi, Biboi is a diminutive form, and its appellative equivalent could be bibu, denoting, among other things, 'cradle pole', '(well) sweep', but also 'bar'. The latter meaning alludes to the variously etymologised Balto-Finnic hero name Kalev (which patronymics are Kalevipoeg, Kalevanpojat), which has also entered the list of names of Russian bylina heroes as a patronymic Kolyvanovich. Relying on the etymology proposed by $\mathrm{P}$. Ariste, who derived the name Kalev from the dialectal word kali, meaning 'a wooden bar' (Ariste 1946), the names Kalev and Biboi would be semantically close. It can even be further speculated that the Vepsians must have known other narratives connected to the name, but the name survived only in the tale under discussion here. Be that as it may, but Biboi is still quite exceptional among the proper names in the tale in that while in Finnish variants the hero has relatively ordinary Finnish names and in Russian variants the names are less ordinary, substratal names of Balto-Finnic (perhaps Vepsian) origin, the only Vepsian name is ethnic, but just uncommon from the modern viewpoint.

Y. Smirnov's study (1972) aims to complement K. Chistov's one with new Russian variants and analogies from the folklore of other nations, but also to contest his arguments. Smirnov particularly questioned the linking of the story to the Vepsians, as 
neither of them had come across a single Vepsian variant. The Vepsian variants and onomastic data available now enable to confirm the role of the Vepsians in mediating the tale to the Russians, but perhaps also to other Balto-Finnic peoples. There is no doubt, however, that the story could not have originated among the Vepsians or the Sami, because it was known among the Kets, a linguistically isolated indigenous tribe in Northern Eurasia.

Since Smirnov, as was the case with Chistov had no access to the published Siberian (Ket and Selkup) or Finnish texts, he has, besides making several valuable observations in his work, taken a step back in comparison with Chistov. The Komi parallels are probably in the genetic relationship with the corresponding BaltoFinnic and Russian ones, but these motifs are rather secondary and beside the point (cf. e.g. the mittens or skis under the corner of the house, etc.) for this discussion. Bashkirian and particularly South-Slavonic parallels bear only very superficial resemblance. Both share some universal features, like the treachery of the wife and the help of the son(s). Single references to the Russian bylinas, however, are suggestive of the author's unfortunately failing attempts to prove as if the Rahta tales could have roots in the Old Slavonic tradition.

In the following I will attempt to answer the question of the roots of the tales, even though I am quite confident that it can be done in a very indeterminate manner, because these roots remain too far from us in time and space. The tale appears to have found its invariant plot thousands of years ago somewhere in Northern Siberia. The folklore of Siberian people, both those of the Uralic language family and others, contains various stories about conflicts between one's own people and foreigners, merciless and reasonable. Wife kidnapping is often the most common reason for an attack. There is even a story where the wife quickly surrenders to the stronger aggressor and makes no attempt to save her husband, but his little son who accidentally survived remembers the crime and takes his revenge (Pelikh 1972: 361364). These tales were told and probably things like that happened. Likewise, a son may have saved his father in a hopeless situation, or the daughter may have followed her mother's example and repudiated her father. Perhaps the older tradition even included a witty saying, which someone had said in a situation of life and death. And probably there was a storyteller who once 
took all the vaguely structured tales and combined these into one clear-cut coherent tale, which the listeners could not forget or mix up with others, and which began to spread and vary, though still retaining its invariant contents.

The invariant could be described as follows: Once there lived "our" man with his wife, daughter and son. There came men from another tribe, and seeing that they can overpower the man, they decided to kill him and take the wife (or the wife and the daughter). The man is tied to the tree. Women acquiesce to the situation and make no attempt to help the doomed man. The daughter speaks about the enemy as her new father. When the enemies are sound asleep with the mother and daughter, the son sneaks out and cuts through the father's bonds. He also brings him a weapon (a spear) and the father kills the sleeping enemies, and then his wife and daughter with it, reminding them their behaviour and words. He leaves with his son to continue his life elsewhere.

Evidently, the original plot of the tale is quite similar to the Ket variants. This does not mean that the story originates from among the Kets, but it is quite reasonable to assume that they have preserved it in its original form, as their lifestyle remained the same over a long time. Several details of the tale, which sound illogical in all the European redactions, begins to make sense in the Ket variants. For example, why was the man not killed at once, and the slaying postponed until the next morning? Was it because the enemies wanted him to feel the fear of death and taunt him, which was exactly what the enemy who had slept with his wife did by asking him about the dream? Being tied up in the entrance room or to the stove was certainly not very comfortable, but if it was compared to being left outside to be eaten by gnats? In the (probably original) Ket variant the man's confinement also marked the beginning of his execution. The enemies had probably planned a much more gruesome death for him, which also explains his unmerciful revenge.

The great number of enemies in Europe, who were either robbers or representatives of a foreign or hostile tribe, has introduced the turn of the plot where the enemy army sleeps separately in a building further away from the house, either in the sauna or thresher, or in the barn (in the Sami variant). The motif of destroying the enemy army by burning them in or by pulling 
down the building and felling it upon the sleeping army is definitely a later addition to the plot. Burning someone in is known from other stories about the times of hostility, whereas pulling down the house would require the protagonist's supernatural strength, which as I have already mentioned, was also a later addition.

Two Ket variants depict the daughter in the age of sexual maturity, but in the third variants the daughter is still a child. In the variants of other peoples the daughter is depicted as a child. Here it is rather difficult to determine which possibility could have come first. Two enemies could have easily defeated a man of normal physical strength, which, again, would lead to the speculation that both had a personal interest in it. Another possibility is that the man is attacked only by one strong chief, or by a group of a couple of men, one of whom will get the wife and the others help him on the principle that enemies should be harmed at any cost. In any case it is obvious that the child daughter character would be more creative, since the conduct of children of about the same age is much more expressive. In this case the family is divided in two ways: into couples man-wife and sondaughter by age, and father-son and mother-daughter by gender. This forms a very precise and balanced structure, which alone confirms that the story could not have emerged independently in Siberia and among the Balto-Finnic people and the Sami. This possibility is further confirmed by coincidental details, like the conversation about dreams and the daughter calling the enemy, who had bedded her mother, her father (or, more commonly, 'new father', but also 'fat father' as in the Ket text).

The original and invariant plot has been modified according to the time and situation. For example, in a Finnish variant the father asks the son to bring him matches to burn through the bonds (which is quite a modern means!). Major changes, however, have emerged after the merging of motifs from historical narratives or folk tales.

Next to the Ket variants, which appear to have retained the original plot, the most problematic variant is the only existing Selkup text. In this variant the man exhibits heroic powers and his wife active treachery: she had made a deal with the robber chief and she is the key to her husband's defeat. This differs 
from the provoked violation of a taboo in the Vepsian, Karelian and Russian variants because here the wife tempts her husband to demonstrate his strength by making him tear up stronger and stronger bonds. The man tears up all the bonds, but when the wife ties a wired string around his wrists, he can no longer free himself. Chaining with cunningness is very characteristic of fairy tales, but the situation sounds relatively modern. Since the capturing of the man takes place the same way in a Russsian variant, it leads to the assumption that the Selkups have borrowed the redaction from the Russians, who had voluntarily settled in Siberia or had been deported there. Considering the stability of the plot among the neighbouring Kets, we may assume that the plot was also known in the earlier Selkup tradition and may have even facilitated the adoption of the new redaction, which was familiar but also new and intriguing. Of course, it is possible that the Selkup as well as other Samoyed and Finno-Urgic traditions still contain this ancient story in its (near) original form, and perhaps it is even recorded, but has not been found in the archives so far.

Quite thought-provoking is the fact that the tale is not known in the Estonian folklore; as to the Livonians and Balto-Finnic peoples in Ingria, the absence of the tale could be explained by the small number of the people and the late folklore collection. It can be speculated that the tale used to be known also in the Estonian tradition, though if this would be the case why has it disappeared, while several other ancient tales with Siberian parallels are still known? Wars and plunders which devastated the country have strongly affected the Estonian oral heritage. But could the later events, such as the Great Northern War which prevails in the Estonian narrative history, help to preserve this ancient plot through associations?

It is certainly possible that the Estonians have never heard the tale. One reason for it may be the different relations of cultural and natural landscape in the Estonian tradition and the northern and eastern Balto-Finnic traditions. The tale preconditions a scattered settlement, but also vast forest areas where the enemies or robbers could hide.

Another interesting fact is that these Balto-Finnic people whose tradition includes the tale under discussion must have been in 
contact with the Sami either in the prehistoric period or later. Had this been the case then the tale had been introduced in the Vepsian, Karelian and Finnish repertoire as a substratum or loan from the Sami. The Sami folklore is known to include many Siberian elements, many of which have been transmitted to the tradition of Balto-Finnic peoples. The fact that this ancient story entered the Russian tale repertoire as a Balto-Finnic substratum has already been confirmed by Chistov, and the information presented in this article should convince that next to the Karelians the Vepsians played an important role in communicating the tale.

Having studied the migration route and history of the tale I heard in the Ladva village, it continued to haunt me. The tale haunted me like it had probably haunted people from different tribes and language varieties throughout thousands of years, and who have tried to let it go by passing it on. As for me, retelling the tale or contemplating about its distribution and origin was not enough. Perhaps the tumultuous times of the second half of the 1980s made me think about the ideology of this grim story.

The protagonist of the tale is a man/ landlord/ father, who is either a nameless representative of his people, or a named and remembered ancestor. He is in the centre of action and remains active throughout the tale, even when he is bound, because he is awake when everyone else is asleep. The protagonist is a hero, accustomed to the harsh climate, omnipresent dangers and primitively inhuman customs. He is a solitary hero and he fights first and foremost about survival. The idea of continuance and future perspectives, embodied by his son, follows after. At the same time it is his son who ensures the survival of the father in a critical moment.

The son was his last chance, after his wife and daughter had repudiated the doomed husband and father. Considering the pair mother-daughter from a feminist perspective, it becomes quite evident that the creation of these characters (assuming that they are fictitious) is highly chauvinistic. Furthermore, the emphasis is on the daughter, as mere wife's betrayal would not be half as shocking, because firstly, the story would continue the tediously familiar tradition of treacherous wives in oral and written literature, and secondly, her behaviour could be even justified to a 
certain degree. The wife might have come from another tribe, or have been even kidnapped. Perhaps the wife bore a grudge against her husband all along, or perhaps the enemy was more attractive to her than her own husband ever was. Moreover, a husband is traditionally not considered one's flesh and blood, a fact which in the old days was considered much more important than could be imagined nowadays (I remember asking an old woman from Pecoila whether she mourned her late husband. She replied: "Mijäg mužzikad voikta, ved hän veraz om!" - "Why should one mourn one's husband, he is a stranger!").

The daughter, however, repudiated her own flesh and blood, when her father's life was at stake. And she did not just repudiate him by refusing to help out of cowardliness, because the enemies were so overpowering. The daughter's conduct was not merely induced by the wish to save one's neck, but was the manifestation of true callousness, when she told the father, begging for help, to be quiet and reminds him the death that awaits him, or even threatens to tell on him to the "new father", even adding in one Russian variant that "the new father will stab you". Paradoxically, she seems to be concerned only about "the new father", who would be in danger if her own father happened to get free. Can this be explained by adolescent arrogance, which may lead to serious consequences? Or has it been the intention of the creators and transmitters of the tale (who have been predominantly male, as is characteristic of narrative history in general) to emphasise that a representative of the fairer sex, no matter what her age or size, is innately evil, unreliable and malicious? Still, if this be the case, we should not make generalisations about the ideology of the tale and put all blame on men. Consideration of folklore in its entirety, as all the repertoire of an ethnic group, reveals widely different, often even contradictory attribution of values to various social, moral, religious, and other issues. Folklore has introduced us radically different characters: innocent suffering but also guileful women, honest and treacherous men, brave men and women, but also lazy men and women. Among the most influential Estonian folk songs are, for example, "Mehetapja Maie" ('Song of Maie') and "Naisehukkaja Tooma laul" ('The Song of Toomas, the Wife Killer'). The regilaul tradition was mostly transmitted by women who were not considering it offensive to the 
whole womankind that Maie slayed her own husband, without even a hint to the possible motive.

As I already mentioned, of all the characters in the tale, the conduct of the daughter is particularly unacceptable. But even though the character is memorable owing to her gloating remarks, her role in the tale is secondary. She is not the reason why the father is left for gnats to eat or to be killed by the enemies. It is the son who determines the course of events, and the daughter's character functions as his negative image to make the younger brother appear particularly bright and exemplary.

The character of the son is also quite memorable. His young age and small height is suggested by the fact that he cannot reach the knife on a high shelf. In many variants he is eager to help his father before the latter has even asked him. Typically to his young age he is also depicted as weak and sentimental, and may sometimes break down in tears.

"Do you need your father?" is the question which is directly said out in the Ket variant, though allusions to this also appear elsewhere. In fact, this is one of the fundamental questions of humankind even today. Millions of people today are faced with the same question: Do you have the courage to accept an inheritance that will not yield profit but will probably cause much trouble? Do you need your language if the number of people who can speak it is very small and in which you cannot receive formal education? Do you need your culture? Do you need you poor homeland? All these categories are like the father, who "will be killed anyway tomorrow".

The son in the tale may seem to embody a childlike loyalty, but his conduct symbolises an important decision. By saving his father he proves that he wants to accept and pass on his ethnic heritage. In this light it is quite significant that the only other character who is given a name in the Ket variant is the son. He is the true hero of the tale.

\section{References}

AA = Andreev, Nikolai 1929. Ukazatel' skazochnykh siuzhetov po sisteme Aarne. Leningrad 1929.

Ariste, Paul 1946. Kalevist. Looming 7-8, pp. 922-925. 
AT = Aarne, Aarne \& Thompson, Stith 1961. The Types of the Folktale: A Classification and Bibliography. A. Aarne's Verzeichnis der Märchentypen (FF Communications No. 3). Thompson, Stith (trans. and enlarg.). $2^{\text {th }}$ Revision. Folkore Fellows Communications 75: 184. Helsinki: Suomalainen Tiedeakatemia.

Chistov, Kirill 1958. Bylina "Rahta Ragnozerskii" i predanie o Rahkoe iz Ragnozero. Slav'ianskaia filologiia Philologie slave: Sbornik statei. Moskva: Izdatel'stvo Akademii Nauk SSSR, pp. 358-388.

Chistov, Kirill 1959. Materialy k izucheniyu byliny o Rahkoye iz Ragnozera. Voprosy literatury i narodnogo tvorchestva. Petrozavodsk 1959, pp. 122-166.

Dulz'on, Andrei 1964. Ketskiye skazki i drugiye teksty. Sbornik statei po voprosam iazykoznaniia i metodike prepodavaniia inostrannykh iazykov. Uchenye zapiski: Tomskii gosudarstvennyi pedagogicheskii institut 21: 1. Tomsk: Izdatel'stvo Tomskogo Universiteta, pp. 132-134.

Dulz'on, Andrei 1966. Ketskiye skazki. Tomsk: Izdatel'stvo Tomskogo Universiteta.

Dulz'on, Andrei 1969. Ketskiye skazki i drugiye teksty. Ivanov, Viacheslav (ed.). Ketskii sbornik: Mifologiya, etnografiya, teksty. Moskva: Glavnaja Red. Vostocnoj Literatury Nauka, pp. 189-192.

Dulz'on, Andei 1972. Skazki narodov Sibirskogo Severa. Tomsk: Izdatel'stvo Tomskogo Universiteta.

Krinichnaya, Neonila 1978. K problemy tipologii predanii o zaselenii i osvojenii kraya: Po materialam severnykh predanii. Folkloristika Karelii: Sbornik statei. Petrozavodsk: Karel'skij Filial Akademii Nauk SSSR, pp. $23-40$.

Loorits, Oskar 1927 Vägilaste prototüüpe. Album M. J. Eiseni 70. sünnipäevaks. Tartu: Tartu: Eesti Kirjanduse Selts, pp. 37-71.

Pelikh, Galina 1972. Proiskhozhdenie sel'kupov. Tomsk Izdatel'stvo Tomskogo Universiteta.

Rausmaa, Pirkko-Liisa (ed.) \& Salo, Matti (trans.) 1969. A catalogue of historical and local legends in the Folklore Archives of the Finnish Literature Society. Helsinki: Suomalaisen Kirjallisuuden Seuran kansanrunousarkisto 1969.

Simonsuuri, Lauri 1984. Kotiseudun tarinoita. Kansantarinoita. Vainolaiset liikkeellä. Jyväskylä: Suomalaisen Kirjallisuuden Seura.

Smirnov, Yuri 1972. Predanie o Rahte Ragnozerskom (AA *967) po novym dannym. Azbelev, Sergei (ed.) Russkaia narodnaia proza. Russkii fol'klor 13. Leningrad: Nauka, Leningr. otd-nie, pp. 40-57.

SUS = Sravnitel'nyi ukazatel' siuzhetov, vostochnoslavianskaia skazka. Barag, L. G. \& Berezovskii, I. P. \& Kabashnikov, K. P. \& Novikov, N. V. (sost.). Leningrad: Nauka, Leningr. otd-nie 1979. 